\title{
Development of a duplex SYBR Green I- based quantitative real-time PCR assay for the rapid differentiation of goose and Muscovy duck parvoviruses
}

\author{
Su Lin ${ }^{1+}$, Shao Wang ${ }^{1+}$, Xiaoxia Cheng ${ }^{1}$, Shifeng Xiao ${ }^{1}$, Xiuqin Chen ${ }^{1,3}$, Shilong Chen ${ }^{1}$, Shaoying Chen ${ }^{1,3^{*}}$ \\ and Fusong $\mathrm{Yu}^{2^{*}}$
}

\begin{abstract}
Background: Waterfowl parvoviruses, including goose parvovirus (GPV) and Muscovy duck parvovirus (MDPV), can cause seriously diseases in geese and ducks. Developing a fast and precise diagnosis assay for these two parvoviruses is particularly important.

Results: A duplex SYBR Green I-based quantitative real-time PCR assay was developed for the simultaneous detection and differentiation of GPV and MDPV. The assay yielded melting curves with specific single peak $\left(\mathrm{Tm}=87.3 \pm 0.26^{\circ} \mathrm{C}\right.$ or $\mathrm{Tm}=85.4 \pm 0.23^{\circ} \mathrm{C}$ ) when GPV or MDPV was evaluated, respectively. When both parvoviruses were assessed in one reaction, melting curves with specific double peaks were yielded.

Conclusion: This duplex quantitative RT-PCR can be used to rapid identify of GPV and MDPV in field cases and artificial trials, which make it a powerful tool for diagnosing, preventing and controlling waterfowl parvovirus infections.
\end{abstract}

Keywords: GPV, MDPV, SYBR Green I, Duplex real-time PCR, Parvovirus

\section{Main text}

Waterfowl parvoviruses cause substantial economic loss to waterfowl production worldwide $[9,12]$. Parvoviruses that affect waterfowl are goose parvovirus (GPV) and Muscovy duck parvovirus (MDPV) [6, 31], both of which are members of the Dependovirus genus and Parvoviridae family. GPV and MDPV have linear single-stranded DNA genomes that are approximately $5 \mathrm{~kb}$. The genome contains two large non-overlapping open reading frames (ORFs) flanked by two inverted terminal repeats (ITRs) at the 5 'and $3^{\prime}$ - ends. The left ORF is predicted to encode a nonstructural protein NS, and the right ORF encodes the capsid proteins VP1, VP2 and VP3, which are derived from the same gene and differ in their $\mathrm{N}$-terminal domain $[7,30]$.

\footnotetext{
* Correspondence: 15563356@qq.com; yufusong58@163.com

+Su Lin and Shao Wang contributed equally to this work.

${ }^{1}$ Institute of Animal Husbandry and Veterinary Medicine, Fujian Academy of Agriculture Sciences, Fuzhou 350003, China

${ }^{2}$ Institute of Biotechnology, Fujian Academy of Agricultural Sciences, Fuzhou 350003, China

Full list of author information is available at the end of the article
}

GPV and MDPV possess approximately 77\% homology in the VP1 nucleotide sequences or $85 \%$ at the protein level, and have been shown to be antigenically related to each other [7, 22, 31]. However, both parvoviruses have different hosts: GPV primarily infects geese and ducks, while MDPV infects ducks only $[3,9,14,20]$. The classical method used to detect GPV and MDPV includes virus isolation and serological assays like seroneutralisation test $(\mathrm{SN})$, latex particle agglutination test (LPA) and indirect immunofluorescence assays (IFA) [2, 10, 21, 33]. Despite of their precision and reliability, these methods are labor-intensive and time consuming. On the other hand, conventional polymerase chain reaction (PCR) and loop-mediated isothermal amplification assay (LAMP) [13, 15] were applied for fast identification of both viruses, but they do not quantify viral load, an important factor to measure for pathogenic and epidemiological studies.

Quantification method to detect waterfowl parvoviruses was previously reported using a TaqMan-based real-time PCR reaction containing primers targeting the parvovirus,

(C) The Author(s). 2019 Open Access This article is distributed under the terms of the Creative Commons Attribution 4.0 International License (http://creativecommons.org/licenses/by/4.0/), which permits unrestricted use, distribution, and reproduction in any medium, provided you give appropriate credit to the original author(s) and the source, provide a link to the Creative Commons license, and indicate if changes were made. The Creative Commons Public Domain Dedication waiver (http://creativecommons.org/publicdomain/zero/1.0/) applies to the data made available in this article, unless otherwise stated. 
as well as a probe labeled with fluorescent reporter dyes. However, these assays were not developed to differentiate GPV and MDPV [11, 16, 24, 28]. The method relying on a SYBR Green fluorescent quantitative PCR was also applied for detection and quantification of other viruses [23, 29]. Furthermore, it has been used to distinguish different virus DNAs in one reaction based on the peaks in the melting curves resulting from the difference in the $T \mathrm{~m}$ values of the PCR products [1, 32]. Here, we developed a duplex SYBR Green-I based quantitative real-time PCR to rapidly and specifically amplify a region of the GPV and MDPV genome that can be used to distinguish infection by either virus in a single reaction.

Complete genome sequences of GPV strains (GenBank Accession No. HQ891825, JF926695 and KU844283) and MDPV strains (GenBank Accession No. NC_006147 and KU844281) [4-6] were aligned using DNAMAN Version 8 (DNASTAR, Madison, WI, USA). The alignment was used to identify conserved and diverged regions between the two parvoviruses. Based on the alignment, two pair of oligonucleotides SYBR Green primers specific to GPVs and MDPVs were designed in the VP1 gene using Primer Premier version 5 (PREMIER Biosoft International, Palo Alto, California, USA). The primers for GPV were G5-P1 (5' - GAGGTAGACAGCAACAGAAA-3') and G5-P2 (5' - GCTCGTCCGTGACCATA-3'), and it amplified a $343 \mathrm{bp}$ product. The primers for MDPV were M3-P1 (5' TAATGGTGGCAGGAATGCACAGTTC-3') and M3P2 (5' - TGTTACCATGATGTCTGAAAT-3'), which amplified a $331 \mathrm{bp}$ region. The $T \mathrm{~m}$ values of the two PCR products were $87.5 \pm 0.3{ }^{\circ} \mathrm{C}$ for GPV and $86.05 \pm$ $0.21^{\circ} \mathrm{C}$ for MDPV.

PCR products from GPV and MDPV were cloned into a pMD19-T vector to construct the plasmids pGDA (for GPV) and pMP (for MDPV) using DNA Ligation Kit and E.coli Competent Cell JM109 from Takara Biotechnology (Dalian) Co., Ltd.

The Real-time PCR reactions were performed using SYBR $^{\oplus}$ Premix Ex Taq ${ }^{\mathrm{Ts}}$ (Tli RNaseH Plus) kit (Takara Biotechnology (Dalian) Co., Ltd) with a Mastercycler ${ }^{\circledR}$ ep realplex system (Eppendorf, Germany) to detect SYBR Green. The reaction was conducted in $20 \mu \mathrm{L}$ volume and the optimized final reaction conditions contained $10 \mu \mathrm{L}$ SYBR $^{\odot}$ Premix Ex TaqTM (Tli RNaseH Plus), $0.5 \mu \mathrm{L}$ each of $10 \mu \mathrm{M}$ forward and reverse primer for both GPV and MDPV, $1 \mu \mathrm{L}$ of DNA template $(0.2 \sim 20 \mathrm{ng})$ and $6 \mu \mathrm{L}$ of deionized water to a final volume of $20 \mu \mathrm{L}$. The thermal programme was as follows: denaturation at $95^{\circ} \mathrm{C}$ for $5 \mathrm{~min}$, 40 cycles of denaturation at $95^{\circ} \mathrm{C}$ for $15 \mathrm{~s}$, annealing at $60{ }^{\circ} \mathrm{C}$ for $10 \mathrm{~s}$ and extension at $72^{\circ} \mathrm{C}$ for $15 \mathrm{~s}$.

Successive ten-fold dilutions of the standard plasmids pGDA or pMP with copy numbers ranging from $1 \times$ $10^{1} \sim 1 \times 10^{8}$ copies/ $\mu \mathrm{L}$ were used to construct the standard curve for each parvovirus. Each dilution was tested in triplicates. The standard curve of GPV was linear for $1 \times$ $10^{1} \sim 1 \times 10^{8}$ copies $/ \mu \mathrm{L}$, with the correlation coefficient (R2) of 0.993 and efficiency $E=100 \%$ (Fig. 1a). The standard curve of MDPV was linear in $1 \times 10^{1} \sim 1 \times 10^{8}$ copies $/ \mu \mathrm{L}$, with the correlation coefficient (R2) 0.992 and efficiency $\mathrm{E}=109 \%$ (Fig. 1b). Using this method, we were able to calculate viral copy number using these standard formulas for the regression analysis: $\mathrm{Y}=-3.325 \mathrm{X}+37.58$ (GPV) and $\mathrm{Y}=-3.132 \mathrm{X}+37.3(\mathrm{MDPV})$. This result also indicated that the detection limits of the real-time PCR assay for GPV or MDPV was $10^{1}$ copies.

After the PCR cycles, a melting curve was generated (with the annealing temperatures $60^{\circ} \mathrm{C}$ to $95^{\circ} \mathrm{C}$ at a linear transition rate of $0.1{ }^{\circ} \mathrm{C} / \mathrm{s}$, where the reaction was held at $16^{\circ} \mathrm{C}$ upon completion) to discriminate between the specific amplicons and the non-specific amplification products. The melting peaks were visualised by plotting the negative derivative of the fluorescence intensity over temperature versus the annealing temperature $(-\mathrm{dI} / \mathrm{dT}$ versus $\mathrm{T})$ produced by the Mastercycler ${ }^{\bullet}$ ep realplex system software 2.0 (Eppendorf, Germany). The $T \mathrm{~m}$ value was defined as the peak of the curve. Single and duplex quantitative PCR were conducted using single or double standard plasmids (pGDA and pMP) described above. The specific single peak of melting curve corresponding to a single GPV template was detected at $T \mathrm{~m}=$ $87.3 \pm 0.26^{\circ} \mathrm{C}$, and a specific single peak for MDPV was detected at $\mathrm{Tm}=85.4 \pm 0.23^{\circ} \mathrm{C}$. When both viruses were included in one reaction, double peaks for both parvoviruses were detected at $T \mathrm{~m}=87.7 \pm 0.24^{\circ} \mathrm{C}$ for $\mathrm{GPV}$ and $\mathrm{Tm}=84.7 \pm 0.28^{\circ} \mathrm{C}$ for MDPV (Fig. 2).

The specificity of the assay was perform using DNA from GPV, MDPV and other waterfowl viruses. Viral DNA was extracted using a QIAamp DNA Mini Kit (QIAGEN) according to manufacturer's instructions. GPV and MDPV strains, Novel Duck Reovirus (NDRV), Muscovy Duck Reovirus (MDRV), Duck hepatitis virus (DHV), Duck plague virus (DPV) and Goose Paramyxovirus (GPMV) reference strains were obtained from the Laboratory of Animal Viral Diseases at the Institute of Animal Husbandry \& Veterinary Medicine, Fujian Academy of Agricultural Sciences, Fujian, China. Egg Drop Syndrome Virus (EDSV) strain was obtained from the China Institute of Veterinary Drug Control. The tested DNA concentrations ranged from 0.3 to $25.5 \mathrm{ng} / \mu \mathrm{L}$. We did not detect fluorescent signals from other waterfowl viruses (Fig. 3), supporting that the assay is specific to GPV and MDPV.

A series ten-fold dilution of the pGDP and pMP plasmids from $10^{6}$ to $10^{8}$ copies $/ \mu \mathrm{L}$ was conducted to calculate the coefficients of variation (CVs) for intra- and inter-assay variation in cycle threshold $(\mathrm{Ct})$ values for the real-time PCR assay. The mean intra and inter CV for GPV were $0.87 \sim 3.05 \%$ and $1.51 \sim 3.60 \%$, respectively, and the mean 

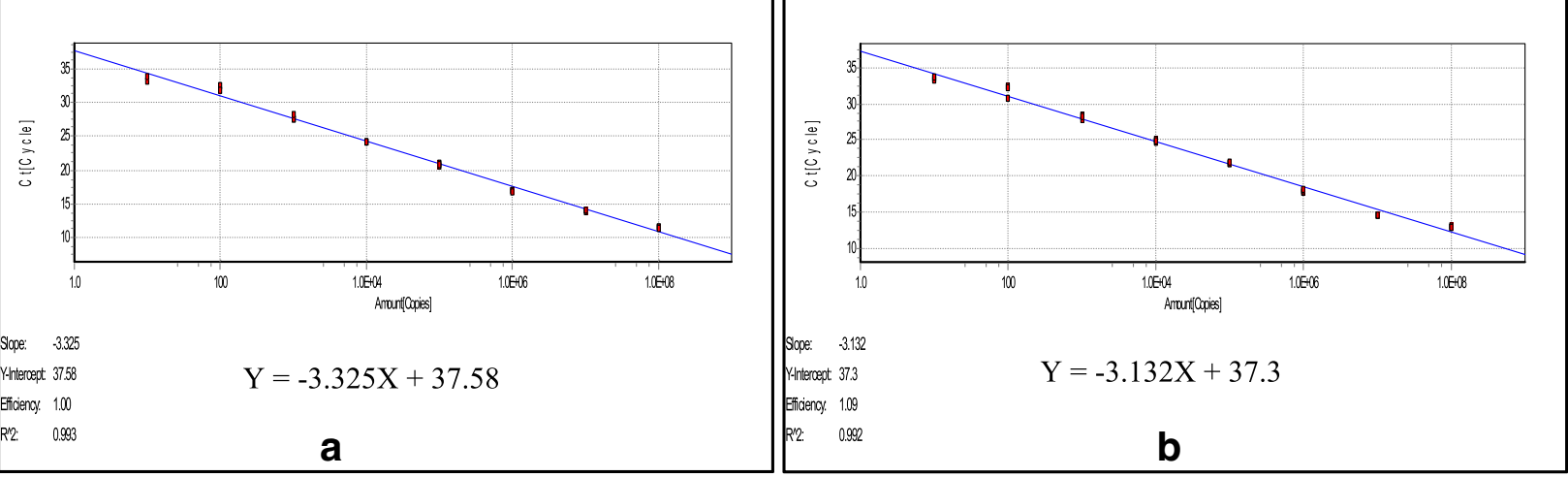

Fig. 1 Standard curves of the duplex real-time PCR assay to measure viral copy number of GPV and MDPV. Standard curves for (a). GPV and (b) MDPV. The $x$-axis indicates the copy number, ranging from $1 \times 10^{1} \sim 1 \times 10^{8}$ copies $/ \mu \mathrm{L}$, used in the experiments. The $y$-axis represents the corresponding cycle threshold $(\mathrm{Ct})$ values. Each data point was amplified in triplicate of each dilution, and the equation below the graph is the standard formulate for regression analysis to calculate viral copy number for (a) GPV and (b) MDPV

intra and inter $\mathrm{CV}$ for $\mathrm{MDPV}$ were $0.44 \sim 2.21 \%$ and $1.29 \sim 1.73 \%$, respectively (Table 1 ).

To evaluate the application of the assay, a total of 65 artificial infected specimens and 15 field-isolated samples were collected. The artificial infections were conducted in mule ducklings by oral infection with GPV or MDPV strains isolated in the laboratory. The field isolated were collected from suspected cases of GPV or MDPV in goslings and ducklings. Viral DNA were isolated and tested for GPV and MDPV using the duplex real-time PCR assay as described above. The results indicated that 41 of the 65 artificial samples were infected with GPV, which had single peaks in the melting curves at $T \mathrm{~m}=$ $87.3 \pm 0.32{ }^{\circ} \mathrm{C}$ and the other 24 samples were infected with MDPV, resulting in single melting peaks at $T \mathrm{~m}=85.2 \pm$ $0.26^{\circ} \mathrm{C}$. Among the 15 filed isolated specimens, two were

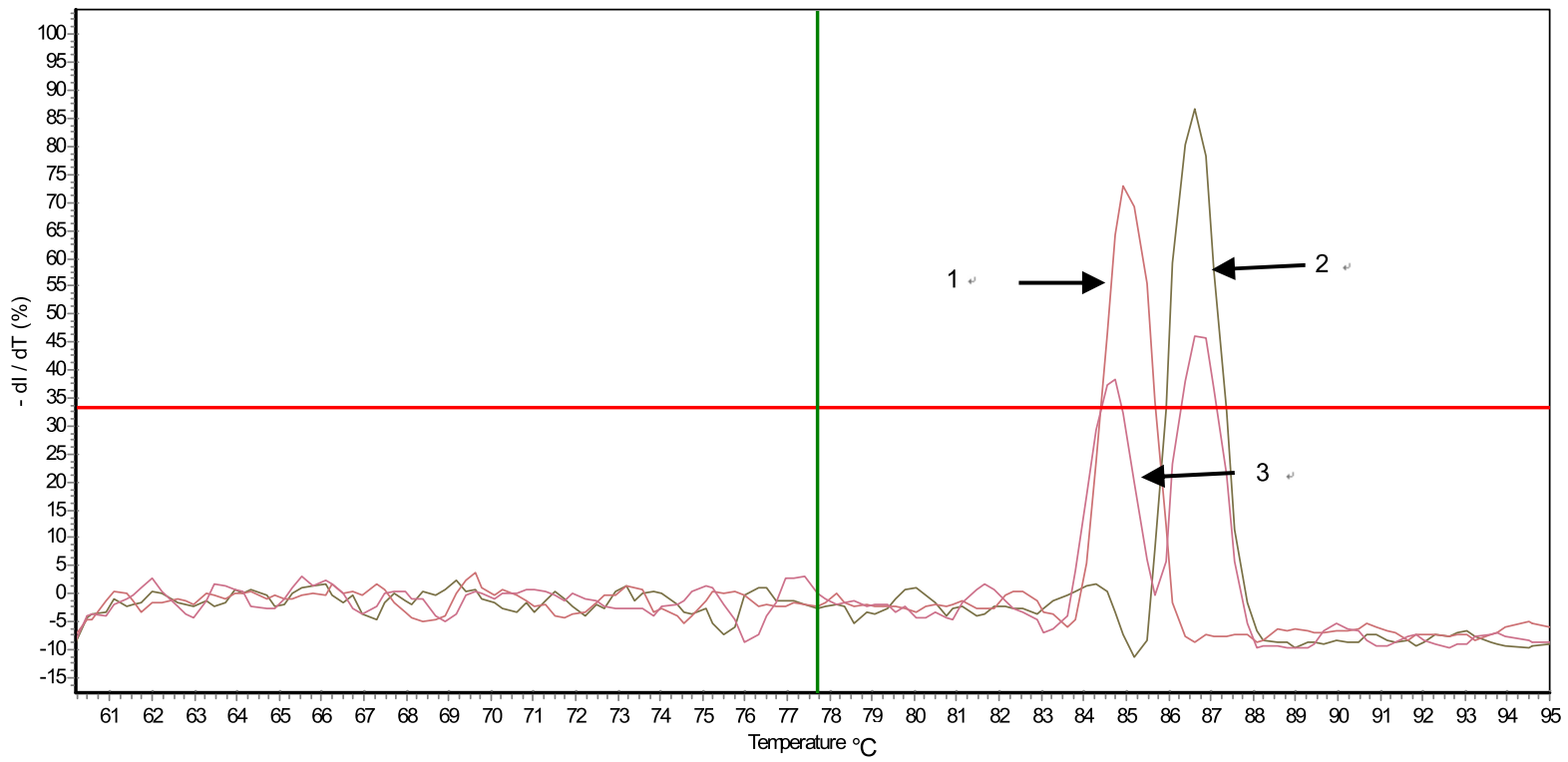

Threshold: $33 \%$

Fig. 2 Melting curves of a duplex real-time PCR assay to detect GPV and MDPV. Peaks labeled with the numbers correspond to the viruses as follows: 1, MDPV; 2, GPV; 3, GPV and MDPV. The peaks of melting curves represent the point of inflection of the fluorescence decreasing, which corresponds to the templates that are used in the real-time $P C R$ reactions 


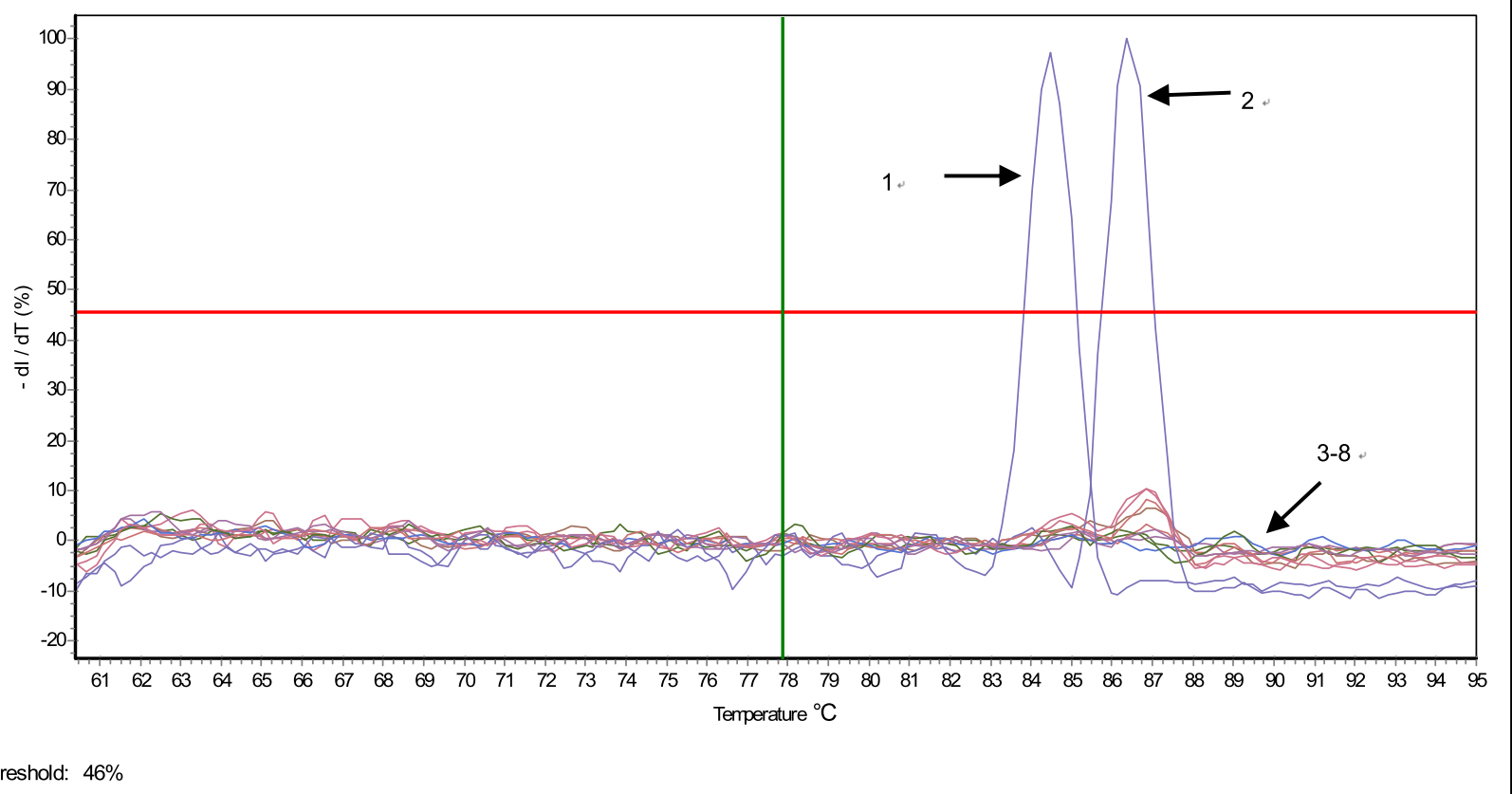

Fig. 3 Duplex real-time PCR assay detected GPV and MDPV but not other waterfowl viruses. Fluorescence was detected from (1) MDPV and (2) GPV samples, and fluorescence signal was not observed in the (3-8) control groups, including Novel Duck Reovirus (NDRV), Muscovy Duck Reovirus (MDRV), Duck hepatitis virus (DHV), Duck plague virus (DPV), Goose Paramyxovirus (GPMV) and Egg Drop Syndrome Virus (EDSV) strains

identified as positive for both GPV and MDPV, seven were positive for GPV only, two were positive for MDPV only, and four were negative for either parvovirus. We verified these results using an indirect immunofluorescence assays (IFA) according to the method described by [4]. All the results were consistent between the two methods (data not shown).

Using the $\mathrm{Ct}$ value determined from the standard curves, we also demonstrated the viral load of parvoviruses in swab specimens of the cloaca and oropharynx collected from an artificial infection trial conducted in mule ducklings. The dynamic of virus excretion via different

Table 1 Variance analysis of Ct values for real-time PCR assay

\begin{tabular}{|c|c|c|c|c|c|c|}
\hline \multirow{3}{*}{$\begin{array}{l}\text { Concentration } \\
\text { of standard plasmid } \\
\text { (DNA copies } / \mu \mathrm{L} \text { ) }\end{array}$} & \multicolumn{3}{|c|}{ Intra-assay variability } & \multicolumn{3}{|c|}{ Inter-assay variability } \\
\hline & \multicolumn{2}{|l|}{$\overline{C T}$} & \multirow[t]{2}{*}{ CV (\%) } & \multicolumn{2}{|l|}{$\mathrm{CT}$} & \multirow[t]{2}{*}{ CV (\%) } \\
\hline & Mean & SD & & Mean & SD & \\
\hline \multicolumn{7}{|l|}{ GPV } \\
\hline $1 \times 10^{8}$ & 10.72 & 0.17 & 1.59 & 10.64 & 0.16 & 1.51 \\
\hline $1 \times 10^{7}$ & 14.60 & 0.45 & 3.05 & 14.39 & 0.32 & 2.24 \\
\hline $1 \times 10^{6}$ & 17.47 & 0.15 & 0.87 & 17.13 & 0.62 & 3.60 \\
\hline \multicolumn{7}{|c|}{ MDPV } \\
\hline $1 \times 10^{8}$ & 13.31 & 0.12 & 0.92 & 13.18 & 0.19 & 1.47 \\
\hline $1 \times 10^{7}$ & 16.04 & 0.35 & 2.21 & 15.99 & 0.21 & 1.29 \\
\hline $1 \times 10^{6}$ & 18.02 & 0.08 & 0.44 & 17.93 & 0.31 & 1.73 \\
\hline
\end{tabular}

routes after oral infection with a short beak and dwarfism syndrome virus (SBDS-GPV) strain [17] was intermittently determined by the real-time PCR assay. Viral DNA was isolated from swabs samples by the DNA extraction kit described above. The viral copy numbers in swab specimens of the cloaca ranged from $10^{3.28}$ to $10^{5.49}$ copies $/ \mu \mathrm{L}$ at 3-21 days post infection, while the oropharynx swab samples had viral load of $10^{3.72}$ to $10^{5.21}$ copies/ $\mu \mathrm{L}$ at 310 days post infection. For cloaca and oropharynx swabs, viral load reached the highest level at 5 days post infection. Using the IFA method, we only detected the virus at 510 days post infection from the cloaca, suggesting that the presented real-time PCR was more sensitive than the serological IFA assay (Table 2).

Table 2 Viral load values of SBDS-GPV in cloaca and oropharynx swabs detected by real time PCR assay

\begin{tabular}{lllll}
\hline $\begin{array}{l}\text { Swab Samples } \\
\text { Days post infection }\end{array}$ & $\begin{array}{l}\text { Cloaca } \\
\text { Real-time } \\
\text { (copies number) }\end{array}$ & $\begin{array}{c}\text { Oropharynx } \\
\text { (FA }\end{array}$ & $\begin{array}{l}\text { Cloaca } \\
\text { IFA }\end{array}$ & \begin{tabular}{l} 
Oropharynx \\
\hline $3 \mathrm{~d}$
\end{tabular} \\
\hline $10^{4.54}$ & $10^{4.64}$ & $0 / 4$ & $0 / 4$ \\
$5 \mathrm{~d}$ & $10^{5.49}$ & $10^{5.21}$ & $2 / 4$ & $0 / 4$ \\
$7 \mathrm{~d}$ & $10^{4.17}$ & $10^{3.72}$ & $3 / 4$ & $0 / 4$ \\
$10 \mathrm{~d}$ & $10^{4.53}$ & $10^{3.74}$ & $1 / 4$ & $0 / 4$ \\
$14 \mathrm{~d}$ & $10^{3.52}$ & - & $0 / 4$ & $0 / 4$ \\
$21 \mathrm{~d}$ & $10^{3.28}$ & - & $0 / 4$ & $0 / 4$ \\
\hline
\end{tabular}


Despite the prophylaxis taken against waterfowl parvoviruses, parvovirus outbreaks persist in coastal China where vaccination against parvoviruses is widely used in commercial goose and duck flocks [4, 24, 25, 27]. Phylogenetic analysis of VP genes of these newly emerged parvovirus strains indicated that adaptive evolution and genome recombination had occurred due to the accumulation of point mutations and the co-infections among waterfowl parvovirus variants $[18,25,26]$. Therefore, having a fast and precise diagnosis assay for these two parvoviruses is particularly important. In this study, we developed an optimized duplex SYBR Green-I based fluorescence quantitative PCR to detect GPV and MDPV. The primers sequences which were selected in the VP1 sequence of parvovirus based on the compassion of several variants from different subgroups of GPV and MDPV were found to be conserved in spite of those point mutations observed in the last two decades [8, 19, 22, 26]. Therefore, this assay can be used to detect the viruses quickly, and precisely differentiate between GPV and MDPV in one reaction using a melting curves analysis. The method also provides quantitative data that may be used to inform pathogenesis or epidemiological studies, and this was unachievable by conventional PCR or LAMP analyses that have been used until now.

In conclusion, we report a duplex real-time PCR assay that can quantitatively detect and distinguish GPV and MDPV in waterfowl specimens. The assay is rapid, sensitive, specific and reproducible, and will serve as a useful tool for diagnosing, preventing and controlling waterfowl parvovirus infections.

\section{Abbreviations \\ Ct: Cycle threshold; CV: Coefficients of variation; DHV: Duck hepatitis virus; DPV: Duck plague virus; EDSV: Egg drop syndrome virus; GPMV: Goose paramyxovirus; GPV: Goose parvovirus; IFA: Indirect immunofluorescence assays; ITR: Inverted terminal repeat; LAMP: Loop-mediated isothermal amplification assay; LPA: Latex particle agglutination test; MDPV: Muscovy duck parvovirus; MDRV: Muscovy duck reovirus; NDRV: Novel duck reovirus; ORF: Open reading frame; PCR: Polymerase chain reaction; SBDS-GPV: Short beak and dwarfism syndrome virus; SN: Seroneutralisation test}

\section{Acknowledgements}

This work was supported by the National Key Research and Development Program of China (2016YFD0500805-4) and the Fujian Public Welfare Project (2018R1023-12)

\section{Funding}

This work was supported by the National Key Research and Development Program of China (2016YFD0500805-4) and the Fujian Public Welfare Project (2018R1023-12).

\section{Availability of data and materials}

The datasets used and/or analysed during the current study are available from the corresponding author on reasonable request.

\section{Authors' contributions}

SL and SW are responsible for the primers design, DNA extraction, real-time PCR assay optimization, data analysis and the writing of this manuscript. XXC, SFX, XQC and SLC performed sample collection, virus isolation and animal trials. SYC and FSY are responsible for the research design and guidance. All authors read and approved the final manuscript. SL and SW contribute equally to this paper.

\section{Ethics approval and consent to participate}

All conducted autopsy examinations were done according to international guidelines and recommendations. All animal experiments conducted in the Institute of Animal Husbandry and Veterinary Medicine were approved by Laboratory Animal Bioethics Committee of Institute of Animal Husbandry and Veterinary Medicine in accordance with animal ethics guidelines and approved protocols. The approval numbers of the ethics committee are IAHV-AEC-2017-0927 and IAHV-AEC-2018-0312.

\section{Consent for publication}

Not applicable

\section{Competing interests}

The authors declare that they have no competing interests.

\section{Publisher's Note}

Springer Nature remains neutral with regard to jurisdictional claims in published maps and institutional affiliations.

\section{Author details}

${ }^{1}$ Institute of Animal Husbandry and Veterinary Medicine, Fujian Academy of Agriculture Sciences, Fuzhou 350003, China. Institute of Biotechnology, Fujian Academy of Agricultural Sciences, Fuzhou 350003, China. ${ }^{3}$ Fujian Animal Diseases Control Technology Development Center, Fuzhou 350013, China.

Received: 11 October 2018 Accepted: 20 December 2018 Published online: 10 January 2019

\section{References}

1. Acevedo AM, Perera CL, Vega A, Ríos L, Coronado L, Relova D, Frías MT, Ganges L, Núñez Jl, Pérez LJ. A duplex SYBR Green I-based real-time RT-PCR assay for the simultaneous detection and differentiation of Massachusetts and non-Massachusetts serotypes of infectious bronchitis virus. Mol Cell Probes. 2013;27:184-92.

2. Alexandrov M, Alexandrova R, Alexandrov I, Zacharieva S, Lasarova S, Doumanova L, Peshev R, Donev T. Fluorescent and electron-microscopy immunoassays employing polyclonal and monoclonal antibodies for detection of goose parvovirus infection. J Virol Methods. 1999;79:21-32.

3. Brown KE, Green SW, Young NS. Goose parvovirus - an autonomous member of the dependovirus genus? Virology. 1995;210:283-91.

4. Chen S, Wang S, Cheng X, Xiao S, Zhu X, Lin F, Wu N, Wang J, Huang M, Zheng $M$, Chen S, Yu F. Isolation and characterization of a distinct duckorigin goose parvovirus causing an outbreak of duckling short beak and dwarfism syndrome in China. Arch Virol. 2016;161:2407-16.

5. Cheng X, Chen S, Zhu X, Chen S, Lin F, Wang S, Cheng Y, Lin T. Isolation and identification of goose parvovirus from Muscovy ducklings [in Chinese]. Fujian Nongye Xuebao. 2008;23:355-8.

6. Cheng Y, Lin T, Hu Q, Li Y, Zhou W, Wu Z. Isolation and identification of a parvovirus from Muscovy ducklings [in Chinese]. Chin J Virol. 1993;9:228-35.

7. Chu CY, Pan MJ, Cheng JT. Genetic variation of the nucleocapsid genes of waterfowl parvovirus. J Vet Med Sci. 2001;63:1165-70.

8. Fan WT, Sun ZY, Shen TT, Xu DN, Huang KH, Zhou JY, Song SQ, Yan LP. Analysis of evolutionary processes of species jump in waterfowl parvovirus. Front Microbiol. 2017:8:421.

9. Glávits R, Zolnai A, Szabó E, Ivanics E, Zarka P, Mató T, Palya V. Comparative pathological studies on domestic geese (Anser anser domestica) and Muscovy ducks (Cairina moschata) experimentally infected with parvovirus strains of goose and Muscovy duck origin. Acta Vet Hung. 2005;53:73-89.

10. Gough D, Ceeraz V, Cox B. Isolation and identification of goose parvovirus in the UK. Vet Rec. 2005;(13):424.

11. Grzegorz W, Elżbieta S, Wojciech K. Quantitative analysis of waterfowl parvoviruses in geese and Muscovy ducks by real-time polymerase chain reaction: correlation between age, clinical symptoms and DNA copy number of waterfowl parvoviruses. BMC Vet Res. 2012;8:29.

12. Grzegorz W, Wojciech K, Elżbieta S. Genetic variance of Derzsy's disease strains isolated in Poland. J Mol Genet Med. 2009;3:210-6. 
13. Ji J, Xie QM, Chen CY, Bai SW, Zou LS, Zuo KJ, Cao YC, Xue CY, Ma JY, Bi YZ. Molecular detection of Muscovy duck parvovirus by loop-mediated isothermal amplification assay. Poult Sci. 2010;89:477-83.

14. Kisary J. Immunological aspects of Derzsy's disease in goslings. Avian Pathol. 1977;6:327-34

15. Limn CK, Yamada T, Nakamura M, Takehara K. Detection of goose parvovirus genome by polymerase chain reaction: distribution of goose parvovirus in Muscovy ducklings. Virus Res. 1996;1:167-72.

16. Niu X, Chen H, Yang J, Yu X, Ti J, Wang A, Diao Y. Development of a TaqMan-based real-time PCR assay for the detection of novel GPV. J Virol Methods. 2016:237:32-7.

17. Palya V, Zolnai A, Benyeda Z, Kovács E, Kardi V, Mató T. Short beak and dwarfism syndrome of mule duck is caused by a distinct lineage of goose parvovirus. Avian Pathol. 2009;38:175-80.

18. Shen $H$, Zhang $W$, Wang $H$, Zhou $Y$, Shao $S$. Identification of recombination between Muscovy duck parvovirus and goose parvovirus structural protein genes. Arch Virol. 2015;160:2617-21.

19. Shien JH, Wang YS, Chen CH, Shieh HK, Hu CC, Chang PC. Identification of sequence changes in live attenuated goose parvovirus vaccine strains developed in Asia and Europe. Avian Pathol. 2008;37:499-505.

20. Sirivan P, Obayashi M, Nakamura M, Tantaswasdi U, Takehara K. Detection of goose and Muscovy duck parvoviruses using polymerase chain reaction-restriction enzyme fragment length polymorphism analysis. Avian Dis. 1998;42:133-9.

21. Takehara K, Nakata T, Takizawa K, Limn CK, Mutoh K, Nakamura M. Expression of goose parvovirus VP1 capsid protein by a baculovirus expression system and establishment of fluorescent antibody test to diagnose goose parvovirus infection. Arch Virol. 1999;144:1639-45.

22. Tatar-Kis T, Mato T, Markos B, Palya V. Phylogenetic analysis of Hungarian goose parvovirus isolates and vaccine strains. Avian Pathol. 2004;33:438-44.

23. Tian H, Wu J, Shang Y, Cheng Y, Liu X. The development of a rapid SYBR one step real-time RT-PCR for detection of porcine reproductive and respiratory syndrome virus. Virol J. 2010;7:90

24. Wang J, Wang J, Cui Y, Nan H, Yuan W. Development of a tagman-based real-time PCR assay for the rapid and specific detection of novel duckorigin goose parvovirus. Mol Cell Probes. 2017:34:56-8.

25. Wang S, Cheng XX, Chen SY, Lin FQ, Chen SL, Zhu XL, Wang JX. Evidence for natural recombination in the capsid gene VP2 of Taiwanese goose parvovirus. Arch Virol. 2015;160:2111-5.

26. Wang S, Cheng XX, Chen SY, Lin FQ, Chen SL, Zhu XL, Wang JX, Huang MQ, Zheng M. Phylogenetic analysis of VP1 gene sequences of waterfowl parvoviruses from the mainland of China revealed genetic diversity and recombination. Gene. 2016:578:124-31.

27. Wang S, Cheng XX, Chen SY, Zhu XL, Chen SL, Lin FQ, Li ZL. Genetic characterization of a potentially novel goose parvovirus circulating in Muscovy duck flocks in Fujian Province, China. J Vet Med Sci. 2013;75:1127-30.

28. Yang JL, Cheng AC, Wang MS, Pan KC, Li M, Guo YF, Li FL, Zhu DK, Chen XY. Development of a fluorescent quantitative real-time polymerase chain reaction assay for the detection of goose parvovirus in vivo. Virol J. 2009;6:142.

29. Yang Z, Habib M, Shuai J, Fang W. Detection of PCV2 DNA by SYBR Green I-based quantitative PCR. J Zhejiang Univ Sci B. 2007:8:162-9.

30. Zadori Z, Erdei J, Nagy J, Kisary J. Characteristics of the genome of goose parvovirus. Avian Pathol. 1994;23:359-64.

31. Zádori Z, Stefancsik R, Rauch T, Kisary J. Analysis of the complete nucleotide sequences of goose and Muscovyduck parvoviruses indicates common ancestral origin with adenoassociated virus 2. Virology. 1995;212:562-73.

32. Zhao Z, Yu Y, Zhang Z, Liang P, Ma Y, Li S, Wang H. A duplex, SYBR Green I-based RT-qPCR assay for the simultaneous detection of apple chlorotic leaf spot virus and cherry green ring mottle virus in peach. Virol J. 2013;10:255

33. Zhu X, Chen S, Lin F, Cheng X, Chen S, Huang M, Wang S, Li Z Development of the latex agglutination diagnostic method of muscovy duck gosling plague [in Chinese]. Chin J Prevent Vet Med. 2012:34:715-8.

\section{Ready to submit your research? Choose BMC and benefit from:}

- fast, convenient online submission

- thorough peer review by experienced researchers in your field

- rapid publication on acceptance

- support for research data, including large and complex data types

- gold Open Access which fosters wider collaboration and increased citations

- maximum visibility for your research: over $100 \mathrm{M}$ website views per year

At BMC, research is always in progress.

Learn more biomedcentral.com/submissions 